\title{
Enhancement of performance and anti-oxidant variables in broiler chicken fed diets containing sub-optimal methionine level with graded concentrations of sulphur and folic acid
}

\author{
Venkata Rama Rao Savaram ${ }^{1}$,*, Venkata Lakshmi Narasimha Raju Mantena ${ }^{1}$, Shyam Sunder Paul ${ }^{1}$, \\ Nagalakshmi Devanaboyina ${ }^{2}$, Srilatha Thota ${ }^{3}$, Prakash Bhukyaa ${ }^{1}$, and Rajkumar Ullengala ${ }^{1}$
}

\author{
* Corresponding Author: \\ Venkata Rama Rao Savaram \\ Tel: +91-40-24017000, Fax: +91-24017002 \\ E-mail: svramarao1@gmail.com \\ ${ }^{1}$ ICAR-Directorate of Poultry Research, \\ Rajendranagar, Hyderabad, Telangana, \\ 500030, India \\ ${ }^{2}$ Animal Nutrition, PVNR Telangana \\ Veterinary University, Hyderabad, Telangana, \\ 500030, India \\ ${ }^{3}$ Poultry Science, PVNR Telangana Veterinary \\ University, Hyderabad, Telangana, 500030, \\ India \\ ORCID \\ Venkata Rama Rao Savaram \\ https://orcid.org/0000-0002-2054-9055 \\ Venkata Lakshmi Narasimha Raju Mantena \\ https://orcid.org/0000-0001-5175-8784 \\ Shyam Sunder Paul \\ https://orcid.org/0000-0002-9549-5741 \\ Nagalakshmi Devanaboyina \\ https://orcid.org/0000-0002-3630-8774 \\ Srilatha Thota \\ https://orcid.org/0000-0001-5702-3877 \\ Prakash Bhukya \\ https://orcid.org/0000-0003-1857-2464 \\ Rajkumar Ullengala \\ https://orcid.org/0000-0003-2712-6546
}

Submitted Jun 2, 2021; Revised Jul 20, 2021; Accepted Aug 10, 2021
Objective: An experiment was conducted to determine the effects of supplementing graded concentrations of inorganic sulphur (S) without and with folic acid (FA) in maize-soybean meal diets on performance, slaughter and anti-oxidant variables, immune responses and serum protein fractions in broiler chicken.

Methods: Inorganic S was supplemented at $0.05 \%, 0.10 \%, 0.15 \%$, and $0.20 \%$ alone or in combination with FA (4 mg/kg) in basal diet (BD) containing no supplemental methionine (Met) and FA. A control group was fed with the recommended concentration of Met. Each diet was offered to 10 pens of 5 male broiler chicks (Cobb 400) and fed ad libitum from day 1 to 42 .

Results: The broilers fed the BD had lower body weight gain (BWG), feed efficiency (FE), higher lipid peroxidation (LP), lower activity of glutathione peroxidase (GSHPx), lower lymphocyte proliferation ratio (LPR), and reduced concentrations of total protein, albumin, and globulin in serum. Supplementation of FA and S to the BD improved the BWG (all concentrations of S) and FE $(0.20 \%$ S) similar to the control group. Similarly, the combination of $S$ and FA significantly improved the concentrations of total protein, albumin, and globulin in serum, reduced the LP and increased the activity of GSHPx and LPR. However, responses in the above parameters were related to the concentration of $S$ in the diet. The slaughter variables and antibody titres against the Newcastle disease were not affected with the treatments.

Conclusion: Based on the results, it is concluded that the combination of S (0.2\%) and FA $(4 \mathrm{mg} / \mathrm{kg})$ improved the BWG and FE, similarly supplementation of these nutrients improved the concentration of protein fractions and reduced the stress (reduced LP and improved GSHPx) variables in serum and improved the cell mediated immune response (LPR) in broilers fed sub-optimal concentrations of Met in diet.

Keywords: Broiler Chicken; Methionine; Sulfur; Folic Acid; Body Weight; Anti-oxidant Variables

\section{INTRODUCTION}

Major function of dietary methionine (Met) is in protein synthesis, besides its involvement in more than 100 transmethylation reactions in chickens [1], immune modulation [2,3], and anti-oxidant role in glutathione synthesis [4]. Methyl donors (MDs) like choline and betaine are known to reduce the dietary requirement of Met by participation in MD function of the amino acid, and thereby sparing the Met for protein synthesis [5-7]. Thus, fortification of the diet with MD may reduce the dietary requirement of the Met without affecting the bird's performance. Folic acid (FA) is the key vitamin, which plays a 
critical role in the single carbon transfer in the methylation reaction. Furthermore, FA acts as a cofactor in the methylation reactions, which are involved in the synthesis of nucleic acids and amino acids [8]. One of the major functions of FA in the form of tetrahydrofolate is the methylation of homocysteine to Met [9]. By providing adequate or higher concentrations of FA, the Met drain out for methylation could be minimized. Literature suggested that $2 \mathrm{mg} / \mathrm{kg}$ FA is adequate in broiler chicken diet [10]. The findings of Jing et al [11] suggested a higher requirement of FA ( $4 \mathrm{mg} / \mathrm{kg})$ in the diets of egg laying chicken to reduce inflammatory reactions induced by lipopolysaccharide challenge, besides improving the production performance. Such beneficial effects of FA were reported [12] to be mediated by inhibiting the mitogen activated protein kinases and the nuclear factor-kappa B pathways in RAW 264.7 cells.

Physiologically, Met partly spares the requirement of cystine $[5,13]$, which is essential for the synthesis of sulphur (S) compounds like taurine, chondroitin sulfate, etc. Since the Met is a sulphur containing amino acid, supplementation of sulphur salts was reported to improve the performance similar to chicks fed L Met [14] or those fed diets containing MDs like choline [15] and the later workers also emphasized the necessity of S for proper functioning of MD to spare methionine for protein synthesis.

The results from our previous study [3] and other labs [2] suggested that the concentration of Met in diet influences the immune responses in broiler chicken. Additionally, administration of FA was reported to elicit positive response in the immune system in egg laying hens exposed to lipopolysaccharide challenge $[16,17]$. Significant reduction in serum GGT activity in lipopolysaccharide challenged laying hens was also reported with FA (4 mg/kg) supplementation [11]. On similar lines, Huang et al [18] and Joshi et al [19] reported significant increase in the oxidative stress (greater thiobarbituric acid reactive substances concentrations) in the liver of rats fed FA deficient diets, which implies that FA is essential for reduction of oxidative stress. Therefore, supplementation of both S and FA may act additively/ synergistically in sustaining or improving the performance of broiler fed diets containing sub-optimal levels of Met. Therefore, an experiment was conducted to study the effects of graded concentrations of $S$ with or without supplemental FA on performance, carcass variables, immune responses and anti-oxidant indices in broiler chicken fed sub-optimal levels of Met in diet.

\section{MATERIALS AND METHODS}

\section{Birds and management}

Commercial broiler (Cobb 400) male chicks $(\mathrm{n}=500)$ were randomly and equally distributed into 10 dietary groups having
10 replicates with 5 chicks per replicate. The birds were reared in 3-tier battery brooder pens $(47.5$ " $\times 29.5 " \times 17$ ") with wire floor from $\mathrm{d} 1$ to $42 \mathrm{~d}$ of age in an open sided poultry house. Artificial heat was provided with incandescent bulbs to brood the chicks at $35^{\circ} \mathrm{C} \pm 1^{\circ} \mathrm{C}$ up to $7 \mathrm{~d}$ of age, which was gradually reduced to $27^{\circ} \mathrm{C} \pm 1^{\circ} \mathrm{C}$ by $21 \mathrm{~d}$ of age, after which, the broilers were maintained at ambient temperature $\left(24.5^{\circ} \mathrm{C}\right.$ to $\left.35.8^{\circ} \mathrm{C}\right)$. Florescent bulbs were used to provide $22 \mathrm{~h}$ light and $2 \mathrm{~h}$ darkness in a d from $\mathrm{d} 22$ till the end of experiment. Birds were vaccinated against Newcastle (Lasota) disease on d 5 and 21 and infectious bursal disease on 11 and $28 \mathrm{~d}$ of age. The experiment was conducted by following the guidelines of the Institute Animal Ethics Committee (IAEC/DPR/17/1 dated 1st October 2017).

\section{Diets}

Maize and soybean meal based control diets (CD) having 12.33 and $13.17 \mathrm{MJ} / \mathrm{kg} \mathrm{ME}$ and 228 and $189 \mathrm{~g}$ crude protein (CP) $/ \mathrm{kg}$, respectively for starter ( 1 to $21 \mathrm{~d}$ ) and finisher (22 to $42 \mathrm{~d}$ of age) phases were prepared (Table 1). Crystalline Met (DL-Met) was supplemented to the CD to meet the Met requirement of the strain (Cobb 400) of broilers (5.52 and

Table 1. Ingredient and nutrient composition $(\mathrm{g} / \mathrm{kg})$ of control diets (CD) during starter and finisher phases

\begin{tabular}{|c|c|c|}
\hline Items & $\begin{array}{l}\text { Starter } \\
1 \text { to } 21 \mathrm{~d}\end{array}$ & $\begin{array}{l}\text { Finisher } \\
22 \text { to } 42 \mathrm{~d}\end{array}$ \\
\hline \multicolumn{3}{|l|}{ Ingredient (g/kg) } \\
\hline Maize & 559 & 645 \\
\hline Soybean meal, $45 \%$ crude protein & 379 & 284 \\
\hline Soybean oil & 22.0 & 40.7 \\
\hline Common salt & 4.2 & 4.2 \\
\hline Dicalcium phosphate & 20.1 & 12.9 \\
\hline Shell grit & 6.7 & 7.3 \\
\hline DL-methionine ${ }^{1)}$ & 2.36 & 1.07 \\
\hline L-lysine $\mathrm{HCl}$ & 2.53 & 1.00 \\
\hline Premix ${ }^{2)}$ & 3.60 & 3.60 \\
\hline \multicolumn{3}{|l|}{ Nutrient content } \\
\hline Metabolizable energy (MJ/kg) & 12.33 & 13.17 \\
\hline Crude protein $(\mathrm{g} / \mathrm{kg})^{3)}$ & 228 & 189 \\
\hline Lysine $(\mathrm{g} / \mathrm{kg})$ & 14.3 & 10.4 \\
\hline Methionine (g/kg) & 5.52 & 3.93 \\
\hline Methionine $(\mathrm{g} / \mathrm{kg})^{3)}$ & 5.64 & 3.89 \\
\hline Methionine (CD) (g/kg) & 3.28 & 2.85 \\
\hline Methionine $(\mathrm{g} / \mathrm{kg})^{3)}$ & 3.32 & 2.91 \\
\hline Calcium $(\mathrm{g} / \mathrm{kg})^{3)}$ & 8.0 & 8.0 \\
\hline Non-phytate phosphorus (g/kg) & 4.7 & 3.3 \\
\hline Total phosphorus $(\mathrm{g} / \mathrm{kg})^{3)}$ & 7.1 & 5.6 \\
\hline Sulfur $(g / k g)^{3)}$ & 1.92 & 1.59 \\
\hline \multicolumn{3}{|c|}{$\begin{array}{l}\text { 1) Supplemental methionine was removed in basal diets. } \\
\text { 2) Supplies per kg diet: retinol acetate } 2,475 \mu \mathrm{g} \text {, cholecalciferol } 30 \mu \mathrm{g} \text {, } \\
\text { a-tocopherol } 12 \mathrm{mg} \text {, menadione } 2 \mathrm{mg} \text {, thiamine } 1.2 \mathrm{mg} \text {, pyridoxine } 2.4 \\
\text { mg, cyanocobalamine } 0.01 \mathrm{mg} \text {, niacin } 1.9 \mathrm{mg} \text {, pantothenic acid } 12 \mathrm{mg} \text {, } \\
\mathrm{Mn} 50 \mathrm{mg}, \mathrm{Zn} 112.5 \mathrm{mg} \text {, Fe } 60 \mathrm{mg} \text {, Cu } 10 \mathrm{mg} \text { I 1.2, choline } \mathrm{Cl} 0.5 \mathrm{~g} \text {, } \\
\text { hydrated sodium calcium alumino silicate } 1 \mathrm{~g} \text {. } \\
\text { 3) Analyzed values. }\end{array}$} \\
\hline
\end{tabular}


$3.93 \mathrm{~g} / \mathrm{kg}$, respectively in starter and finisher diets). The CD was supplemented with commercial broiler vitamin premix having all the vitamins, except FA $(2 \mathrm{mg} / \mathrm{kg})$, at the recommend concentration. A basal diet (BD) with maize - soybean meal was prepared with nutrient composition similar to that of CD without supplementation of DL-Met and FA (3.28 and $2.85 \mathrm{~g} / \mathrm{kg}$, Met, respectively in starter and finisher diets). The FA deficient $\mathrm{BD}$ was fortified with feed grade inorganic $\mathrm{S}\left(\mathrm{KH}_{2} \mathrm{SO}_{4}\right.$, SD Fine Chemicals) at four graded concentrations $(0.05 \%, 0.10 \%, 0.15 \%$, and $0.20 \%)$. Another set of four diets containing similar concentrations of $\mathrm{S}$ were supplemented with $4 \mathrm{mg} / \mathrm{kg}$ FA (Baden Aniline and Soda Factory). Standard trace minerals premix was included in all the 10 diets, which has the mineral salts in the form of oxide or carbonate. Each diet was allotted to 10 replicates of 5 chicks each by following completely randomized design and fed $a d$ libitum from one to $42 \mathrm{~d}$ of age. The FA concentration in the premix was estimated using UV spectrophotometric method using distilled water as blank at absorbance of $281 \mathrm{~nm}$ [20]. The concentration of $S$ in compounded diets was estimated with AAS (Analyst 400; Perkin Elmer, Shelton, CT, USA) using nitrous oxide -acetylene flame [21]. The quantity of maize was altered to adjust the graded quantities of $\mathrm{KH}_{2} \mathrm{SO}_{4}$ to make the diet $100 \%$.

Parameters recorded: Body weight and feed intake (FI) per replicate were recorded at 21 and $42 \mathrm{~d}$ of age. Body weight gain (BWG) and FI per bird were calculated for each replicate. Feed efficiency (FE) was calculated as BWG/FI.

Blood sample (about 3 to $4 \mathrm{~mL}$ ) was collected from the brachial vein of one bird in each replicate at $42 \mathrm{~d}$ of age to analyze the concentrations of total protein and albumen in serum utilizing diagnostic kits (Product No 72111 and 72131, respectively, M/S Qualigens India, Mumbai, India).

At $43 \mathrm{~d}$ of age, one bird from each replicate having the body weight nearest to the average of the replicate $( \pm 3 \%)$ was slaughtered by cervical dislocation to study the carcass variables. Weights of ready-to-cook yield (without liver, gizzard, and heart), abdominal fat and breast meat were recorded and expressed as $\mathrm{g} / \mathrm{kg}$ pre-slaughter live weight of the respective bird.

The oxidative parameters like lipid peroxidation (LP) and the activities of anti-oxidative enzymes like RBC catalase (RBCC) and glutathione peroxidase (GSHPx) in blood were measured. About two $\mathrm{ml}$ of blood was drawn from the brachial vein of one bird per replicate at $43 \mathrm{~d}$ of age into a centrifuge tube containing citrate buffer $(1.5 \mathrm{~mL} / 10 \mathrm{~mL}$ blood) for erythrocyte separation and antioxidant enzyme estimation. The blood samples were centrifuged at $500 \times \mathrm{g}$ for $15 \mathrm{~min}$ at $4^{\circ} \mathrm{C}$ to separate buffy coat (WBC) and form erythrocyte pellet. The erythrocytes were washed thrice with PBS (pH 7.4). The packed RBC obtained was mixed with an equal volume of PBS and then diluted as per the requirement with distilled water.

The LP was estimated by quantifying malonyl dialdehyde (MDA), a secondary product of LP. The MDA reacts with 2-thiobarbituric acid to form a trimethine colored substance (pink chromogen), which was extracted into butanol. The color intensity was measured at $548 \mathrm{~nm}$. The LP activity in the erythrocytes was expressed in $\mathrm{nmol} \mathrm{MDA} / \mathrm{mg}$ protein [22].

The enzyme catalase decomposes $\mathrm{H}_{2} \mathrm{O}_{2}$ and the rate of decomposition as measured in terms of reduction in absorbance is indicative of the enzyme activity in the serum sample [23]. The RBCC activity was expressed as units per $g$ of hemoglobin $(\mathrm{Hb})$ after estimating $\mathrm{Hb}$ concentration in the haemolysate.

The activity of GSHPx was estimated following the method of Paglia and Valantine [24].

The effect of $S$ concentration alone in the presence of FA on cell mediated immunity (CMI) (in vitro lymphocyte proliferation ratio, LPR) and humoral immune (HI) (antibody response against Newcastle disease vaccine) were studied. Blood samples were collected at $20 \mathrm{~d}$ of age from one bird per replicate in all the treatments to study the CMI and $\mathrm{HI}$ responses.

The difference between the in vitro proliferation of lymphocytes with and without the stimulant (concanavalin A, Con A) was expressed as the ratio. The LPR was assayed using MTT tetrazodium salt (3-(4,5-dimethylthiazol-2-yl)-2, 5-diphenyl tetrazolium bromide) [25]. About $2 \mathrm{~mL}$ of blood was collected from the brachial vein of the bird in a centrifuge tube containing heparin disodium salt $(5 \mathrm{mg})$. One bird from each replicate was used to collect blood samples at $20 \mathrm{~d}$ of age. The un-clotted blood sample was layered gently over histopaque 1077 (Sigma, Mumbai, India) and centrifuged at $500 \times \mathrm{g}$ for 20 minutes at $4^{\circ} \mathrm{C}$. The cellular band at the interface was collected and transferred to another tube and washed 3 times with RPMI 1640 medium (AL 028A, Himedia, India). The viable cells were counted by using the trypan blue dye exclusion method and the cell concentration was adjusted to $1 \times 10^{7}$ cells/ mL of RPMI 1640 medium. These cells $\left(10^{5}\right.$ purified lymphocytes) were used to measure lymphocyte proliferation by adding $10 \mu \mathrm{L}$ of suspension to each well of a 96-well flat bottom sterile tissue culture plate. Con A (0.9 $\mu \mathrm{g}$ in $150 \mu \mathrm{L} \mathrm{RPMI} /$ well) was used as the stimulant for lymphocyte proliferation. The plate was incubated at $37^{\circ} \mathrm{C}$ and $5 \% \mathrm{CO}_{2}$ concentration for $69 \mathrm{~h}$ in a humid atmosphere, then $20 \mu \mathrm{L}$ MTT $(10 \mathrm{mg} / \mathrm{mL})$ was added to each well and the plate was re-incubated for $3 \mathrm{~h}$. At $72 \mathrm{~h}, 100 \mu \mathrm{L}$ of $4 \% 1$ $\mathrm{N} \mathrm{HCl}$ - isopropanol was added to each well and mixed thoroughly with a micropipette to dissolve the formazin crystals, which gave a deep purple colour. The colour intensity was measured in an ELISA reader (V.200.1, $\mu$ Quant; Biotek Instruments, Inc., Winooski, VT, USA) at $550 \mathrm{~nm}$. 
The LPR was calculated as (OD of well with Con A - OD of well without Con A)/OD of well without Con $\mathrm{A}$.

The broilers were vaccinated against ND by ocular route at 5 and $21 \mathrm{~d}$ of age with Lasota strain (ND Lasota Vac-500; Indivax Pvt., Ltd., Hyderabad, India). At $20 \mathrm{~d}$ of age, $2 \mathrm{~mL}$ of blood was collected from one bird per replicate and the antibody titres in sera against Newcastle disease vaccine were measured [26] by haemagglutination test.

\section{Statistical analysis}

The data were analysed by one-way analysis of variance to test the effect of dietary treatment on various dependant variables studied in the experiment (SPSS, 2002). Replicate mean was considered as the experimental unit for performance variables, while the data of each bird were considered as the experimental unit for slaughter, immune responses, serum analysis and anti-oxidant variables. The treatment means were compared with Tukey's test at $\mathrm{p}<0.05$.

\section{RESULTS}

\section{Performance and slaughter variables}

Body weight gain and FE at day 21 and 42 reduced significantly $(\mathrm{p}<0.05)$ in broilers fed low-Met BD compared to those fed the CD (Table 2). At both 21 and $42 \mathrm{~d}$ of age, supplementation of the $\mathrm{BD}$ with graded concentrations of $\mathrm{S}$ did not improve ( $p>0.05)$ the performance variables. However, fortification of the BD with FA along with $S$ significantly $(\mathrm{p}<0.05)$ improved the BWG higher than the BD. Among the $\mathrm{S}$ and FA combinations, the BWG in S0.10FA group was similar to those fed the $\mathrm{CD}$ at $21 \mathrm{~d}$ of age. While at the end of experi- ment (42 d), both BWG and FE in the S0.2FA group was significantly higher than the $\mathrm{BD}$ and was also similar to those fed the CD having the recommended concentrations of Met. Ready to cook yields and the relative weights of breast meat and abdominal fat were not affected $(\mathrm{p}>0.05)$ by the treatments employed in the current study (Table 2).

\section{Serum protein fractions}

Though the concentration of albumin was not affected ( $\mathrm{p}>$ 0.05 ), the concentrations of total protein (TP) and globulin reduced significantly $(\mathrm{p}<0.05)$ by feeding the $\mathrm{BD}$ which had no supplemental Met (Table 3). Concentrations of all the protein fractions were not affected by supplementation of the BD with graded concentrations of S. Supplementation of FA along with $S$ at $\geq 0.1 \%$ significantly improved the TP concentration compared to the $\mathrm{BD}$ and was equal to the $\mathrm{CD}$. At the highest concentration of S ( $0.2 \%)$ with FA (S0.20 FA), the serum TP concentration was significantly higher than those fed the CD. Similarly, the albumin concentrations in S0.10 FA or S0.20 FA groups were higher than those fed the CD or $\mathrm{BD}$. The serum globulin concentration increased significantly higher than the BD group when the broilers were fed with the BD with different concentrations of S $(0.05 \%$ to $0.20 \%$ ) along with FA.

\section{Anti-oxidant variables and immune responses}

Feeding the low Met BD significantly $(\mathrm{p}<0.05)$ increased the LP (concentration of MDA) compared to the CD fed group (Table 4). Supplementation of $S$ alone at all the concentrations did not reduce the LP. However, combination of $S$ at all concentrations with FA significantly reduced the LP com-

Table 2. Performance and slaughter variables of broilers fed graded levels of sulphur (S) with and without folic acid (FA) (4 mg/kg) in diets containing sub-optimal levels of methionine

\begin{tabular}{|c|c|c|c|c|c|c|c|}
\hline \multirow{3}{*}{ Treat } & \multicolumn{4}{|c|}{ Performance } & \multirow{2}{*}{\multicolumn{3}{|c|}{$\begin{array}{l}\text { Slaughter variables } \\
\text { (g/kg live weight) }\end{array}$}} \\
\hline & \multicolumn{2}{|c|}{1 to $21 \mathrm{~d}$} & \multicolumn{2}{|c|}{1 to $42 \mathrm{~d}$} & & & \\
\hline & BWG (g) & FI/BWG & BWG (g) & FI/BWG & RTC & Breast & Abd fat \\
\hline Control & $946.9^{A}$ & $0.779^{A}$ & $2,639^{A}$ & $0.614^{A}$ & 738.7 & 224.7 & 13.26 \\
\hline Basal & $715.3^{D}$ & $0.705^{\mathrm{C}}$ & $2,237^{C}$ & $0.573^{C}$ & 729.0 & 204.2 & 18.94 \\
\hline SO. $05^{1)}$ & $757.7^{C D}$ & $0.722^{\mathrm{BC}}$ & $2,303^{\mathrm{C}}$ & $0.573^{C}$ & 721.0 & 197.6 & 16.68 \\
\hline S0.101) & $757.9^{C D}$ & $0.717^{\mathrm{BC}}$ & $2,375^{\mathrm{BC}}$ & $0.567^{C}$ & 729.2 & 213.9 & 19.27 \\
\hline S0.151) & $773.2^{\mathrm{BCD}}$ & $0.723^{\mathrm{BC}}$ & $2,375^{\mathrm{BC}}$ & $0.571^{\mathrm{C}}$ & 732.4 & 212.5 & 19.08 \\
\hline S0.201) & $807.1^{\mathrm{BCD}}$ & $0.721^{\mathrm{BC}}$ & $2,313^{B C}$ & $0.579^{\mathrm{BC}}$ & 734.3 & 212.4 & 16.64 \\
\hline S0.05 FA & $850.1^{\mathrm{BC}}$ & $0.737^{\mathrm{ABC}}$ & $2,416^{\mathrm{BC}}$ & $0.571^{c}$ & 744.5 & 218.6 & 18.33 \\
\hline S0.10 FA & $857.5^{\mathrm{AB}}$ & $0.737^{\mathrm{ABC}}$ & $2,440^{\mathrm{ABC}}$ & $0.585^{\mathrm{ABC}}$ & 732.7 & 218.9 & 16.54 \\
\hline S0.15 FA & $836.5^{\mathrm{BC}}$ & $0.733^{\mathrm{ABC}}$ & $2,435^{\mathrm{ABC}}$ & $0.594^{\mathrm{ABC}}$ & 726.1 & 214.5 & 14.36 \\
\hline S0.20 FA & $841.3^{\mathrm{BC}}$ & $0.754^{\mathrm{AB}}$ & $2,528^{A B}$ & $0.611^{\mathrm{AB}}$ & 737.3 & 220.9 & 20.28 \\
\hline P & 0.001 & 0.001 & 0.001 & 0.001 & 0.944 & 0.124 & 0.147 \\
\hline N & 10 & 10 & 10 & 10 & 10 & 10 & 10 \\
\hline SEM & 8.895 & 0.0038 & 18.02 & 0.0025 & 3.33 & 2.06 & 0.594 \\
\hline
\end{tabular}

BWG, body weight gain; FI, feed intake; RTC, ready to cook yield; Abd fat, abdominal fat; FA, folic acid; P, probability; SEM, standard error mean.

1) S0.05, S0.10, S0.20: sulfur $0.05 \%, 0.10 \%, 0.15 \%$, and $0.20 \%$, respectively.

A-D With different superscript in the same parameter differ $(p<0.05)$. 
Table 3. Concentration $(\mathrm{g} / \mathrm{dL})$ of different protein fractions in serum of broiler chicken fed graded levels of sulphur (S) with and without folic acid (FA) (4 mg/kg) in diets containing sub-optimal levels of methionine

\begin{tabular}{lccc}
\hline Treat & Total protein & Albumin & Globulin \\
\hline Control & $2.577^{\mathrm{BC}}$ & $0.279^{\mathrm{B}}$ & $2.298^{\mathrm{AB}}$ \\
Basal & $1.274^{\mathrm{D}}$ & $0.323^{\mathrm{B}}$ & $0.951^{\mathrm{C}}$ \\
S0.05 $^{1)}$ & $1.500^{\mathrm{D}}$ & $0.280^{\mathrm{B}}$ & $1.220^{\mathrm{C}}$ \\
S0.10 $^{1)}$ & $1.359^{\mathrm{D}}$ & $0.533^{\mathrm{AB}}$ & $0.826^{\mathrm{C}}$ \\
S0.15 & $1.830^{\mathrm{CD}}$ & $0.536^{\mathrm{AB}}$ & $1.294^{\mathrm{C}}$ \\
S0.20 & $1.737^{\mathrm{CD}}$ & $0.522^{\mathrm{AB}}$ & $1.215^{\mathrm{C}}$ \\
S0.05 FA & $1.700^{\mathrm{CD}}$ & $0.517^{\mathrm{AB}}$ & $1.183^{\mathrm{B}}$ \\
S0.10 FA & $3.345^{\mathrm{AB}}$ & $0.731^{\mathrm{A}}$ & $2.614^{\mathrm{A}}$ \\
S0.15 FA & $3.413^{\mathrm{AB}}$ & $0.531^{\mathrm{AB}}$ & $2.882^{\mathrm{A}}$ \\
S0.20 FA & $3.800^{\mathrm{A}}$ & $0.693^{\mathrm{A}}$ & $3.107^{\mathrm{A}}$ \\
P & 0.001 & 0.001 & 0.001 \\
N & 6 & 6 & 6 \\
SEM & 0.1328 & 0.0266 & 0.1327 \\
\hline FA folic & &
\end{tabular}

FA, folic acid; P, probability; SEM, standard error mean.

1) So.05, S0.10, S0.20: sulfur $0.05 \%, 0.10 \%, 0.15 \%$, and $0.20 \%$, respectively.

A-D With different superscript in the same parameter differ $(p<0.05)$.

pared to those fed the low Met BD. Though the activity of GSHRx was not affected ( $p>0.05)$, the activities of GSHPx and $\mathrm{RBCC}$ reduced significantly $(\mathrm{p}<0.05)$ in broilers fed the $\mathrm{BD}$ compared to the control group. The GSHPx activity did not differ between the BD and groups fed the BD with different concentrations of S. However, the combination of FA with $S(0.10 \%$ to $0.20 \%)$ significantly $(\mathrm{p}<0.05)$ improved the enzyme activity. Though the activity of RBCC affected with the treatment, the trend was not clear to infer any specific trend to relate to the treatment effect. Antibody titre against
ND was not affected ( $>0.05)$ by the treatments employed, while the LPR reduced significantly in broilers fed the low Met $\mathrm{BD}$ compared to the $\mathrm{CD}$. The LPR increased when $\mathrm{S}$ was included alone at higher concentrations $(0.15 \%$ and $0.20 \%)$ compared to the BD. Similarly, the combination of FA and S at all inclusion levels significantly increased the cell mediated immune response compared to the $\mathrm{BD}$ and was similar or higher (S0.10 FA) compared to the CD fed group.

\section{DISCUSSION}

Significant reduction in the BWG and FE in broilers fed the $\mathrm{BD}$ implies that the Met levels in the BD was sub-optimal. The depressed broiler performance at sub-optimal concentration of Met in maize-soybean meal based diet was observed in our previous studies [7,27]. In the current study, supplementation of $\mathrm{S}$ alone though showed trend of improvement with the concentration $(0.05 \%$ to $0.2 \%)$, the difference was non-significant. However, the combination of FA with $S$ at higher concentrations of $S(\geq 0.10 \%)$ improved the performance. The results indicate additive effect of FA and $S$ on the performance of broilers fed Met deficit diet. Similarly, Harms and Miles [28] reported additive effect of supplemental S $\left(\mathrm{K}_{2} \mathrm{SO}_{4}\right)$ and $\mathrm{MD}$ (choline) on BWG in turkey poults. The improvement in broiler performance with FA supplementation along with $S$ could be due to improved protein utilization. Increased concentrations of TP and albumin observed in the $\mathrm{S}$ and FA supplemented groups compared to those fed the $\mathrm{BD}$ also suggest the possible improvement in the availability of protein/amino acids for protein synthesis with the resultant higher weight gain and FE than those fed the BD. The

Table 4. Serum anti-oxidant variables in broiler chicken fed graded levels of sulphur (S) with and without folic acid (FA) (4 mg/kg) in diets containing sub-optimal levels of methionine

\begin{tabular}{|c|c|c|c|c|c|c|}
\hline Treat & $\begin{array}{c}\text { LP } \\
\text { (nM MDA/mg protein) }\end{array}$ & $\begin{array}{c}\text { GSHPx } \\
\text { (Units/mL) }\end{array}$ & $\begin{array}{c}\text { GSHRx } \\
\text { (Units/mL) }\end{array}$ & $\begin{array}{c}\text { RBCC } \\
\text { (Units/g Hb) }\end{array}$ & LPR & $\begin{array}{l}\text { ND titre } \\
(\text { Log 2) }\end{array}$ \\
\hline Control & $1.353^{\mathrm{D}}$ & $76.29^{\mathrm{BC}}$ & 52.76 & $586.8^{A}$ & $0.635^{\mathrm{B}}$ & 4.50 \\
\hline Basal & $1.671^{\mathrm{A}}$ & $69.62^{C}$ & 52.94 & $396.3^{\mathrm{BC}}$ & $0.393^{\mathrm{D}}$ & 4.33 \\
\hline S0.051) & $1.653^{\mathrm{A}}$ & $72.02^{c}$ & 49.88 & $375.9^{C}$ & $0.402^{\mathrm{D}}$ & 5.33 \\
\hline S0.101) & $1.690^{A}$ & $73.28^{C}$ & 50.41 & $517.6^{A}$ & $0.433^{\mathrm{D}}$ & 4.33 \\
\hline So.15 & $1.614^{\mathrm{AB}}$ & $67.98^{\mathrm{C}}$ & 53.50 & $503.9^{\mathrm{AB}}$ & $0.545^{\mathrm{C}}$ & 5.17 \\
\hline SO.201) & $1.589^{\mathrm{AB}}$ & $71.13^{C}$ & 53.28 & $375.9^{C}$ & $0.702^{B}$ & 4.50 \\
\hline S0.05 FA & $1.517^{\mathrm{BC}}$ & $66.13^{\mathrm{C}}$ & 50.98 & $507.0^{A B}$ & $0.687^{B}$ & 4.00 \\
\hline S0.10 FA & $1.514^{\mathrm{BC}}$ & $86.06^{A B}$ & 50.41 & $347.2^{c}$ & $0.815^{\mathrm{A}}$ & 4.50 \\
\hline S0.15 FA & $1.422^{\mathrm{D}}$ & $88.24^{A}$ & 52.94 & $534.5^{\mathrm{A}}$ & $0.642^{B}$ & 4.67 \\
\hline S0.20 FA & $1.320^{\mathrm{D}}$ & $95.03^{A}$ & 54.07 & $360.4^{C}$ & $0.662^{B}$ & 4.17 \\
\hline P & 0.001 & 0.001 & 0.822 & 0.001 & 0.001 & 0.416 \\
\hline $\mathrm{N}$ & 6 & 6 & 6 & 6 & 6 & 6 \\
\hline SEM & 0.0185 & 2.147 & 0.622 & 13.11 & 0.0183 & 0.1289 \\
\hline
\end{tabular}

LP, lipid peroxidation; GSHPx, glutathione peroxidase; GSHRx, glutathione reductase; RBCC, RBC catalase; LPR, lymphocyte proliferation ratio; ND titre, Newcastle disease titre; P, probability; SEM, standard error mean

1) S0.05, S0.10, S0.20: sulfur $0.05 \%, 0.10 \%, 0.15 \%$, and $0.20 \%$, respectively.

A-D With different superscript in the same parameter differ $(p<0.05)$. 
response in performance variables to the FA depends on the levels of sulphur in the diet. Miles et al [15] indicated the necessity of $\mathrm{S}$ for $\mathrm{MD}$ (choline) to spare a maximum amount of Met in chicken diet.

The response of FE to supplemental $\mathrm{S}$ in presence of FA is dependent on the dose of supplemental $S$ and at the highest $\mathrm{S}$ concentration with FA (0.2 FA), the FE was higher than those fed the $\mathrm{BD}$. The improvement in broiler performance with FA and S supplementation could be due to the Met sparing effect of FA and may also partly be due to the availability of $S$ for the synthesis of $S$ containing amino acid (taurine) in broilers [29] fed low Met BD. Since the FA plays a pivotal role in the transmethylation cycle, inclusion of higher concentrations of the vitamin could improve the broiler performance probably by sparing the MD function of dietary Met. One of the major functions of Met in biological systems apart from protein synthesis is the methyl group sparing activity [13]. Being an important methyl group contributor, the FA could support the broiler performance when fed sub-optimal levels of Met in diet. FA also helps in synthesis of Met from homocysteine by donating a methyl group through transmethylation pathways. The published results of our laboratory [7,27] also reported significant improvement in the broiler performance with MD (betaine, FA, biotin) supplementation to low Met maize-soybean meal based diets. Similarly, Pesti et al [30] reported that supplementation of MD (FA, choline, or methionine) significantly improved the growth in broiler chicks (18-d old) fed the BD having sub-optimal concentration $(0.38 \%)$ of Met. The response in performance to the MD supplementation largely depends on the concentration of Met in the $\mathrm{BD}$. At an adequate or higher level of dietary Met, no significant improvement in weight gain was observed with choline supplementation [28]. Similarly, in our previous study [7], Bet supplementation improved performance in broilers fed sub-optimal concentrations (1.5\% or $1.8 \% \mathrm{CP}$ ) of Met in diet, while at the higher levels ( $2.0 \%$ to $2.4 \% \mathrm{CP}$ ), no such beneficial effect on the performance was observed, which indicate the importance of MD supplementation at the lower concentrations of dietary Met.

The improvement in broiler performance observed in the current study with FA supplementation was probably due to improved protein metabolism as reported by Gursu et al [31] and El-Demerdash et al [32] Significant increase in concentrations of various protein fractions (total protein, albumin, and globulin) in serum with S+FA supplemented groups as observed in the current study also suggests improvement in protein utilization. Similar improvement in the concentrations of total protein, globulin, and albumin in plasma or serum with FA supplementation was reported in our previous study [27] and in the literature [31,32].

In the present study, the BWG did not improve when the
BD was supplemented with S alone at graded concentrations, however the combination of $S$ and FA improved the broiler performance. Significant and linear response in FE to dietary FA concentration $(0.24,0.54,1.14$, and $2.34 \mathrm{mg} / \mathrm{kg})$ was reported in the literature [33]. The magnitude of differences in performance with FA depends on the variation in the concentrations of Met and presence of other MD in the test diets. The response to supplemental MD is known to be reduced in diets containing adequate levels of other MD (choline $1,300 \mathrm{mg} / \mathrm{kg}$ ) in the diet [34].

Though the BWG was improved at day 21 with all concentrations of $\mathrm{S}$ in combination with FA, the FE (21 and 42 $\mathrm{d}$ of age) was not affected, except at the highest concentration of S with FA (S0.20\% FA). Thus, the results suggest the need for higher concentrations of $S$ to improve the performance of broilers fed low Met diet. Though the BWG at $42 \mathrm{~d}$ of age in the later groups (S0.20\% FA) was statistically similar to the control groups, the weight gain was considerably less (111 g) compared to the control group. From the literature [35], MD cannot substitute Met for protein synthesis but can spare methyl donor activity. The lack of response in FE (in all groups, except S0.20\% FA) with S and FA supplementation could probably be due to the severe deficiency of Met, which was lower than the minimum required concentration for protein synthesis and therefore, supplementation of the MD (FA) was not able to improve the FE. Similar to these observations, Rostagno and Pack [36] and our previous study [7] also did not find improvement in broiler performance with MD (betaine) supplementation to low-Met basal diet (13.4 and $13.6 \mathrm{~g} / \mathrm{kg} \mathrm{CP}$ ). It is worth noting that in both the current and our previous studies, supplemental Met was not added to the BDs. Therefore, the data thus suggest the importance of maintaining a minimum level of Met in the $\mathrm{BD}$ to elicit any response in performance to the MD supplementation.

At the end of the study (d 42), though the BWG was not significantly affected with $\mathrm{S}$ supplementation, the weight gain showed a trend of improvement with increase in concentration of $S$ in the diet. Similarly, the FE improved significantly in groups fed the highest concentration of $\mathrm{S}$ with FA (S 0.2\% FA) compared to those fed the BD. The literature available on the effect of $S$ on the performance of chicken fed suboptimal levels of Met is scanty. Miles and co-workers [15] reported that sulfate is needed along with MD (choline) to spare the MD function of Met in broiler diet. Contrary to the current results S supplementation was reported to improve the performance of chicken [14,37], which could be due to the use of higher concentrations (up to $0.64 \%$ ) of $\mathrm{Na}_{2} \mathrm{SO}_{4}$ in their experimental diets. Though the exact role of supplemental $\mathrm{S}$ in supporting the performance of broilers fed low Met diet is not known, the positive response of supplemental S was attributed to Met sparing action of sul- 
phate and or as a source of inorganic S [37]. The ability of chicken to synthesize taurine from sulfate [29] could also account for at least part of the beneficial response to the supplemental S.

As the broilers are reared in open type poultry house in majority of the areas in tropical region, the birds are subjected to different stresses like temperature and humidity variations, floor density, microbial challenge, etc. Stress stimulates oxidation process, which leads to oxidation of cell wall lipid membrane and free radical production. The free radicals thus produced are scavenged by anti-oxidant enzymes like GSHPx to convert them in to less harmful substances. In the current study, the LP reduced significantly with S and FA supplementation compared to the $\mathrm{BD}$ fed group and at the higher concentrations of S $(0.15 \%$ and $0.20 \%)$ with FA, the $\mathrm{LP}$ was reduced compared to the $\mathrm{BD}$ and was similar to the control group. Combination of S $(0.10 \%)$ with FA also increased the activity of GSHPx. Thus, the data suggest reduction of stress with S-FA supplementation to the BD. Similar to these findings, Sahin et al [38] reported significant reduction in the serum and tissue MDA (LP) and other stress indices (homocysteine and Adriano corticotrophin hormone) in heat stressed Japanese quails with FA supplementation (1 $\mathrm{mg} / \mathrm{kg}$ ) in diet. The exact mechanism of $\mathrm{S}$ in reducing $\mathrm{LP}$ is not known, however, the possible role of $S$ in synthesizing the S-containing compounds (taurine) [29] might have reduced stress caused by the lower concentration of Met in the diet.

The cell mediated immune response (LPR) improved in broilers fed S-FA combination compared to those fed the $\mathrm{BD}$. The increased immune response might be due to immune modulating effect of FA as reported in the literature $[39,40]$. The role of FA in immunity is not clear. Wintergerst et al [41]. reported that deficiency of FA adversely affected the immune competence and resistance to infections. The improved immune response observed with FA might also be due to enhanced production of total immunoglobulin $G$ with FA supplementation [16]. In the same line, anti-inflammatory properties of FA were also reported $[12,42]$ in the birds challenged with lipo-polysaccharides. The FA supplementation in diet was reported to be essential for immunity $[39,40]$. The possible synthesis of Met from homocysteine in the presence of FA and S might have increased the availability of Met, which is known to have the immune modulator role in chicken $[2,3]$.

\section{CONCLUSION}

Based on the data, it is evident that the combination of $\mathrm{S}$ $(0.2 \%)$ and FA (4 mg/kg) improved the BWG and FE, increased the serum concentration of protein fractions, reduced the stress (reduced LP and improved GSHPx) variables in serum and improved the cell mediated immune response (LPR) in broilers fed sub-optimal concentrations of Met in diet $(3.28$ and $2.85 \mathrm{~g} / \mathrm{kg}$ diet, respectively in starter and finisher phases).

\section{CONFLICT OF INTEREST}

We certify that there is no conflict of interest with any financial organization regarding the material discussed in the manuscript.

\section{FUNDING}

The authors wish to express thanks to the Indian Council of Agricultural Research, New Delhi, India for funding the research work under AP Cess Fund scheme (REF: F. No. 8(43)/ 2016-ASR-III, dated June 2016 P C No 3030428006).

\section{SUPPLEMENTARY MATERIAL}

Data availability: The data that support the findings of this study are available from the corresponding author upon reasonable request.

\section{REFERENCES}

1. Larbier M, Leclerco B. Nutrition and feeding of poultry. Leicestershire, UK: Nottingham University Press; 1992.

2. Takahashi K, Ohata N, Akiba Y. Influence of dietary methionine and cystine on metabolic responses to immunological stress by Escherichia coli lipopolysaccharide injection and mitogenic response in broiler chickens. Br J Nutr 1997;78:81521. https://doi.org/10.1079/bjn19970197

3. Rama Rao SV, Praharaj NK, Panda AK, Reddy MR. Interaction between genotype and dietary concentrations of methionine for immune function in commercial broilers. Br Poult Sci 2003;44:104-12. https://doi.org/10.1080/0007 166031000085283

4. Wang ST, Chen HW, Sheen LY, Lii CK. Methionine and cysteine affect glutathione level, glutathione-related enzyme activities and the expression of glutathione S-transferase isozymes in rat hepatocytes. J Nutr 1997;127:2135-41. https:// doi.org/10.1093/jn/127.11.2135

5. Pesti GM, Benevenga NJ, Harper AE, Sunde ML. Factors influencing the assessment of the availability of choline in feedstuffs. Poult Sci 1981;60:188-96. https://doi.org/10.3382/ ps.0600188

6. Virtanen E, Rosi L. Effects of betaine on methionine requirement of broilers under various environmental conditions. In: Proceedings of the Australian Poultry Science Symposium, 1995; University of Sydney, Sydney NSW, Australia. pp. 88-92.

7. Rama Rao SV, Raju MVLN, Panda AK, Poonam Saharia, 
Shyam Sunder G. Effect of supplementing betaine on performance, carcass traits and immune responses in broiler chicken fed diets containing different concentrations of methionine. Asian-Australas J Anim Sci 2011;24:662-9. https://doi.org/10.5713/ajas.2011.10286

8. Stover PJ. Physiology of folate and vitamin B12 in health and disease. Nutr Rev 2004;62:S3-12. https://doi.org/10. 1111/j.1753-4887.2004.tb00070.x

9. Finkelstein JD, Martin JJ. Methionine metabolism in mammals. Distribution of homocysteine between competing pathways. J Biolog Chem 1984;259:9508-13. https://doi.org/10.1016/ S0021-9258(17)42728-1

10. Whitehead CC, McCormack HA, Rennie JS, Frigg M. Folic acid requirements of broilers. Br Poult Sci 1995;36:113-21. https://doi.org/10.1080/00071669508417757

11. Jing M, Munyaka PM, Tactacan GB, Rodriguez-lecompte JC, House JD. Performance, serum biochemical responses, and gene expression of intestinal folate transporters of young and older laying hens in response to dietary folic acid supplementation and challenge with Escherichia coli lipopolysaccharide. Poult Sci 2014;93:122-31. https://doi.org/10. 3382/ps.2013-03384

12. Feng D, Zhou Y, Xia M, Ma J. Folic acid inhibits lipopolysaccharide-induced inflammatory response in RAW264.7 macrophages by suppressing MAPKs and NF-kB activation. Inflamm Res 2011;60:817-22. https://doi.org/10.1007/s00011011-0337-2

13. Chamruspollert M, Pesti GM, Bakalli RI. Determination of the methionine requirement of male and female broiler chicks using an indirect amino acid oxidation method. Poult Sci 2002;81:1004-13. https://doi.org/10.1093/ps/81.7.1004

14. Tillman PB, Pesti GM. The response of male broiler chicks to a corn-soy diet supplemented with L-methionine, L-cystine, choline, sulfate, and vitamin B12. Poult Sci 1986;65:1741-8. https://doi.org/10.3382/ps.0651741

15. Miles RD, Ruiz N, Harms RH. The interrelationship between methionine, choline, and sulfate in broiler diets. Poult Sci 1983;62:495-8. https://doi.org/10.3382/ps.0620495

16. Munyaka PM, Tactacan G, Jing M, Karmin O, House JD, Rodriguez Lecompte JC. Immunomodulation in young laying hens by dietary folic acid and acute immune responses after challenge with Escherichia coli lipopolysaccharide. Poult Sci 2012;91:2454-63. https://doi.org/10.3382/ps.201202381

17. Munyaka PM, Tactacan G, Jing M, Karmin O, House JD. Response of older laying hens to an Escherichia coli lipopolysaccharide challenge when fed diets with or without supplemental folic acid. Poult Sci 2013;92:105-13. https://doi.org/ 10.3382/ps.2012-02579

18. Huang SR, Hsu Y, Lin HL, Yang FL. Folate depletion and elevated plasma homocysteine promote oxidative stress in rat livers. J Nutr 2001;131:33-8. https://doi.org/10.1093/jn/

\section{1 .33}

19. Joshi R, Adhikari S, Patro BS, Chattopadhyay S, Mukherjee T. Free radical scavenging behavior of folic acid: evidence for possible antioxidant activity. Free Radic Biol Med 2001; 30:1390-9. https://doi.org/10.1016/s0891-5849(01)00543-3

20. Kshirsagar SS, Bhalekar SM, Gopale DK, Shirishkumar DA. Development and validation of new UV- Spectroscopic method for water soluble folic acid. Inter J Chem Concepts 2017:3:364-70.

21. Kirkbright GF, Marshall M. Direct determination of sulfur by atomic absorption spectrometry in a nitrogen separated nitorus oxide-acetylene flame. Anal Chem 1972;44:128890. https://doi.org/10.1021/ac60315a041

22. Placer ZA, Cushman LL, Johnson BC. Estimation of product of lipid peroxidation (malonyl dialdehyde) in biochemical systems. Annals Biochem 1966;16:359-64. https://doi.org/10. 1016/0003-2697(66)90167-9

23. Berg Meye HU. Catalase. In: Berg Meyer HU, editor. Methods of enzymatic analysis. Weinheim, Germany: Verlag Chemie; 1983. Vol 2. pp. 165-6.

24. Paglia DE, Valantine WN. Studies on the quantitative and qualitative characterization of erythrocyte glutathione peroxidase. J Lab Clin Med 1967;70:158-69. https://doi.org/ 10.5555/uri:pii:0022214367900765

25. Bounous DI, Campagnoli RP, Brown J. Comparison of MTT colorimetric assay and tritiated thymidine uptake for lymphocyte proliferation assays using chicken splenocytes. Avian Dis 1992;36:1022-7. https://doi.org/10.2307/1591566

26. Reynolds DL, Maraqa AD. Protective immunity against Newcastle disease: the role of antibodies specific to Newcastle disease virus polypeptides. Avian Dis 2000;44:138-44. https:// doi.org/10.2307/1592517

27. Rama Rao SV, Raju MVLN, Prakash B, Paul SS, Nagalakshmi D. Effect of methyl donors supplementation on performance, immune responses and anti-oxidant variables in broiler chicken fed diet without supplemental methionine. Anim Biosci 2022;35:475-83. https://doi.org/10.5713/ab.20.0812

28. Harms RH, Miles RD. Effects of supplemental methionine and potassium sulfate on the choline requirement of the turkey poult. Poult Sci 1984;63:1464-6. https://doi.org/10.3382/ ps.0631464

29. Martin WG, Miraglia RJ, Spaeth DG, Patrick H. Synthesis of taurine from sulfate by the chick. Proc Social Exper Biolog Med 1966;122:841-4. https://doi.org/10.3181/00379727122-31265

30. Pesti GM, Rowland GN, Ryu KS. Folate deficiency in chicks fed diets containing practical ingredients. Poult Sci 1991;70: 600-4. https://doi.org/10.3382/ps.0700600

31. Gursu MF, Onderci M, Gulcu F, Sahin K. Effects of vitamin $\mathrm{C}$ and folic acid supplementation on serum paraoxonase activity and metabolites induced by heat stress in vivo. Nutr Res 2004;24:157-64. https://doi.org/10.1016/j.nutres.2003. 


\subsection{8}

32. El-Demerdash F, Yousef M, Elaswad F. Biochemical study on the protective role of folic acid in rabbits treated with chromium (VI). J Environ Sci Health B 2006;41:731-46. https://doi.org/10.1080/03601230600704282

33. Ryu KS, Pesti GM, Roberson KD, Edwards Jr, HM, Eitenmiller $\mathrm{RR}$. The folic acid requirements of starting broiler chicks fed diets based on practical ingredients. 2. Interrelationships with dietary methionine. Poult Sci 1995;74:1456-62. https:// doi.org/10.3382/ps.0741456

34. Ryu KS, Roberson KD, Pesti GM, Eitenmiller RR. The folic acid requirements of starting broiler chicks fed diets based on practical ingredients. 1. Interrelationships with dietary choline. Poult Sci 1995;74:1447-55. https://doi.org/10.3382/ ps.0741447

35. Schutte JB, De Jong J, Smink W, Pack M. Replacement value of betaine for DL-methionine in male broiler chicks. Poult Sci 1997;76:321-5. https://doi.org/10.1093/ps/76.2.321

36. Rostagno HS, Pack M. Can betaine replace supplemental DL-methionine in broiler diets? J Appl Poult Res 1996;5: 150-4. https://doi.org/10.1093/japr/5.2.150

37. Ross E, Damron BL, Harms RH. The requirement for inorganic sulfate in the diet of chicks for optimum growth and feed efficiency. Poult Sci 1972;51:1606-12. https:/doi.org/ 10.3382/ps.0511606

38. Sahin K, Onderci M, Sahin N, Gursu MF, Kucuk O. Dietary vitamin $\mathrm{c}$ and folic acid supplementation ameliorates the detrimental effects of heat stress in Japanese quail. J Nutr 2003;133:1882-6. https://doi.org/10.1093/jn/133.6.1882

39. Field CJ, Van Aerde A, Drager KL, Goruk S, Basu T. Dietary folate improves age-related decreases in lymphocyte function. J Nutr Biochem 2006;17:37-44. https://doi.org/10.1016/j. jnutbio.2005.04.010

40. Troen AM, Mitchell B, Sorensen B, et al. Unmetabolized folic acid in plasma is associated with reduced natural killer cell cytotoxicity among postmenopausal women. J Nutr 2006; 136:189-94. https://doi.org/10.1093/jn/136.1.189

41. Wintergerst ES, Maggini S, Hornig DH. Contribution of selected vitamins and trace elements to immune function. Ann Nutr Metab 2007;51:301-23. https://doi.org/10.1159/ 000107673

42. Wang G, Dai J, Mao J, Zeng X, Yang X, Wang X. Folic acid reverses hyper-responsiveness of LPS-induced chemokine secretion from monocytes in patients with hyperhomocysteinemia. Atherosclerosis 2005;179:395-402. https://doi. org/10.1016/j.atherosclerosis.2004.10.033 